\title{
Formación de una motivación positiva estable para estudiar con estudiantes mayores de instituciones de educación militar superior mediante la creación de un ambiente de alta lealtad
}

\section{Formation of a Stable Positive Motivation to Study with Senior Students of Higher Military Educational Institutions by Creating a High Loyalty Atmosphere}

\author{
Ch. V. Grafeeva ${ }^{1}$ \\ Instructor, Military Medical Academy named after S.M. Kirov ${ }^{1}$
}

Orcid ID: https://orcid.org/0000-0001-9615-7173 ${ }^{1}$

Recibido: 03 de enero de 2020

Aceptado: 04 de julio de 2020

\begin{abstract}
Resumen
La relevancia de la investigación está relacionada con el hecho de que en la historiografía doméstica el problema metodológico de las formas de superar las dificultades de aprendizaje, asociado con la falta de motivación interna positiva, no se ha estudiado prácticamente con el aspecto de enseñar inglés a estudiantes de instituciones militares de educación superior. En la historiografía extranjera, los temas de la formación de la motivación bajo ciertas condiciones educativas se consideran bastante ampliamente, sin embargo, sin énfasis en los detalles de la especialización de las instituciones militares de educación superior. El propósito del artículo es presentar los resultados de un estudio empírico realizado en la Academia Médica Militar. Los objetivos del artículo son identificar el nivel de motivación real para aprender inglés entre los estudiantes mayores de la Academia Médica Militar; presentación de los aspectos principales en la metodología de crear un ambiente de alta lealtad en las clases de inglés para estudiantes de último año de la Academia Médica Militar; consideración de nuevas perspectivas para estudios de la correlación entre la atmósfera de alta lealtad y la motivación positiva sostenible de la formación para enseñar inglés a estudiantes de la Academia Médica Militar. El autor del artículo utilizó los siguientes métodos: el análisis de contenido de la literatura científica, el método de observación pedagógica, el análisis de datos estadísticos, así como el método de encuesta sociológica (cuestionario). El autor del artículo verificó la hipótesis científica del estudio a través del experimento sobre la base de la Academia Médica Militar (Moscú). En la parte experimental del estudio, se probaron elementos de la atmósfera de alta lealtad para formar una motivación interna positiva entre los estudiantes mayores de la Academia Médica Militar. Durante el experimento, el autor del artículo logró resaltar la alta eficiencia de la metodología propuesta para enseñar un idioma extranjero mediante el ejemplo de la formación de estudiantes en una universidad militar.
\end{abstract}

Palabras clave: aprendizaje, inglés, idiomas, estudiantes de universidades militares, enfoque comunicativo, competencia comunicativa.

\footnotetext{
${ }^{1}$ Correspondencia al autor 


\section{Abstract}

The research relevance is connected with the fact that in domestic historiography the methodological problem of ways to overcome learning difficulties, associated with the lack of positive internal motivation, has not been practically studied with aspect of teaching English to students of military higher educational institutions. In foreign historiography, the issues of motivation formation under certain educational conditions are considered quite widely, however, without emphasis on the specifics of specialization of military higher educational institutions. The purpose of the article is to present the results of an empirical study conducted at the Military Medical Academy. The objectives of the article are to identify the actual motivation level to learn English among senior students of the Military Medical Academy; presentation of the main aspects in the methodology of creating a high loyalty atmosphere in English classes for senior students of the Military Medical Academy; consideration of further prospects for studies of the correlation between the high loyalty atmosphere and the sustainable positive motivation the formation for teaching English to students of the Military Medical Academy. The author of the article used the following methods: the content analysis of scientific literature, the method of pedagogical observation, statistical data analysis, as well as the method of sociological survey (questionnaire). The author of the article verified the scientific hypothesis of the study through the experiment on the basis of the Military Medical Academy (Moscow). In the experimental part of the study, elements of the high loyalty atmosphere were tested to form a positive internal motivation among senior students of the Military Medical Academy. During the experiment, the author of the article managed to bring out the high efficiency of the proposed methodology for teaching a foreign language by the example of training students in a military university.

Keywords: learning, English, languages, military university students, communicative approach, communicative competence.

\section{Introduction}

The relevance of the research topic is due to the fact that in the context of the requirements of the new generation of Federal state standards, English is one of the compulsory subjects in the universities' curriculum, including non-humanitarian ones. At the same time, the successful educational activity of students directly depends on a high level of motivation and interest in this subject. From this point of view, the problem of forming a positive internal motivation for learning is becoming a key one for students in non-language universities, since most of them demonstrate a lack of interest in learning English, believing it is not necessary for their future professional activities. Meanwhile, in domestic historiography devoted to the formation of motivation in teaching foreign languages, two opposite trends are observed: on the one hand, there is a fairly vast array of theoretical spectrum studies devoted to the learning motivation problems in general and motivation for learning foreign languages in particular. On the other hand, there is a shortage of empirical research papers that would systematically consider factors influencing the formation of positive internal motivation for learning foreign languages among students in non-language universities.

So, in the works of the theoretical direction, motivation is considered by researchers as one of the leading activity factors (Guseva, 2020; Parizi, et al, 2019). The formation of the learning motivation is the solution to questions of personal education (Gerasimova \& Guseva, 
2019: 225). Then, updated learning motives become the stable individual feature. Activity, enthusiasm, responsible attitude to the studied subject are laid in the process of student's learning (Antonian \& Popovych, 2019).

Modern Federal state standards apply an extended approach to the tasks of teaching foreign languages, and the proclaimed main purpose of studying foreign languages is the formation and development of communicative competence (Antonenko, 2018). This requirement cannot be fulfilled in the absence of sustainable internal learning motivation of students studying a foreign language, including the English language as an international communication tool. As a result, practice teachers often face the problem of poor performance, superficial knowledge, and students' reluctance to solve the set educational problems (Maksimenkova, 2019). This thesis is confirmed by numerous empirical studies in domestic and foreign historiography (Antonian \& Popovych, 2019: Nazirova, 2018; Nosova, 2020). Moreover, in the everyday practice of non-linguistic universities, the problem of motivation is paid much less attention than is required for the formation of sustainable internal motivation.

In this context, there is no unified methodological system for monitoring the learning motivation throughout the process of obtaining students' knowledge, methodically developed and included in the teaching load by university teachers. At the same time, without monitoring and identifying the changes' dynamics in students' motivation, it is almost impossible to establish whether a stable and positive cognitive interest in learning a foreign language has been formed (Moiseenko, 2017; Narkevich \& Narkevich, 2018; Osipova, 2018; Popov, 2018; Schwarzkopf, 2018; Sergeeva \& Trubakova, 2017; Tsahaeva et al., 2017).

As a result, the modern classical higher education system is faced with problems of deviant and aggressive behavior, students' reluctance to attend individual subjects precisely because the motivational sphere is not formed at a sufficient level (Kolobaev \& Sinitsyna, 2020: 48). This problem is exacerbated in those universities where there is a strict discipline regime for attending classes, when the lack of learning motivation for foreign languages turns into hidden aggression and suppressed stress. We observed such negative phenomena during practical activities in teaching English to students in the Military Medical Academy. Being a non-linguistic university, this institution, nevertheless, includes in its compulsory curriculum the study of English, according to Federal state standards " +++ ".

Unresolved problems in the motivation field, in turn, become a serious obstacle to the high academic students' performance in the discipline "English". To solve this problem, in the teaching practice course, we developed a methodology for monitoring the motivation of students in military university, as well as identified the main parameters of its formation, the key of which is to create the high loyalty atmosphere in teaching English process. The high loyalty atmosphere in our understanding is a set of the following educational conditions: 
1. An individual approach to each student;

2. The constant communicative openness of the teacher;

3. The presence of a friendly attitude towards students;

4. Leveling of any negative factors in the interaction between teacher and students;

5. A high-degree confidence in the presence of control over educational activities;

6. Non-separation of the students" group into "weak" and "strong" according to the criterion of the English language knowledge;

7. Non-linear training (return to the passed with expanded explanations and additional study of the training material, relying on authentic and relevant text materials and media resources);

8. Creating a "success situation" for students;

9. Work in small groups and use of educational design;

10. Flexible schedule and availability of teacher advice.

The listed conditions, in our opinion, allow to create a learning environment in which students are not stressed, learn to work in a team, and the teacher is not the highest authority issuing instructions, but the moderator of the educational process, directing and correcting students' independent learning activities.

The research subject was the formation of sustainable positive motivation for the English study by students in non-language universities. The object of study was the process of formation of sustainable motivation to learn English among senior students in the Military Medical Academy. The research goal is to identify the influence of high loyalty atmospheric components on the formation of sustainable positive motivation in teaching English to senior students of the Military Medical Academy. Also, the research objectives are the following:

1) consider the main approaches to the motivation study;

2) to present a diagnostic technique for identifying the motivation level among senior students of the Military Medical Academy;

3) evaluate the effectiveness of creating the high loyalty atmosphere in the process of teaching English as a factor in increasing the learning motivation.

Finally, the research hypothesis was: creating an atmosphere of high loyalty allows forming an internal positive motivation to study the discipline "English" among senior students in the Military Medical Academy.

\section{Methods and materials}

The research methodology is based on a communicative approach and includes a group of general scientific methods (analysis, synthesis, deduction, induction), as well as a group of 
special methods: content analysis of research literature, survey method (questionnaire), pedagogical observation method and statistical analysis method.

For a more complete understanding of the effectiveness of the high loyalty atmosphere in the formation of a stable positive learning motivation among senior students in the Military Medical Academy, we have developed a methodology for learning motivation monitoring. The proposed methodology made it possible to conduct an empirical study using the method of sociological survey (questionnaire) among senior students. The general sample of the study for the proposed monitoring methodology was 150 people. The study involved 6 groups of 5 th and 6th course' students studying English.

The empirical study included two stages: the stage of identifying the learning motivation level and the stage of identifying the effectiveness of creating the high loyalty atmosphere to form a positive internal motivation for learning English.

The basis of the methodology for identifying the motivation level are two questionnaires. The first questionnaire includes 6 questions about the students' attitude to "English" as studied discipline. This questionnaire was used at the first stage of an empirical study to identify the level of learning motivation.

Questionnaire No. 1 included the following questions (rate on a 10-point scale):

1. How important is it to learn English for the future military man?

2. How much, in your opinion, will the English language be in demand in your professional activity?

3. Do you like the existing system of teaching English?

4. Do you need to take the initiative in the implementation of educational tasks in the discipline "English"?

5. How complex and incomprehensible, in your opinion, are the teacher' explanations?

6. How difficult for you is it to focus on English learning?

The second questionnaire also consists of 10 questions about each condition of the high loyalty atmosphere. This questionnaire was used at the second stage of an empirical study to identify the level of effectiveness of a high loyalty atmosphere technique to form a stable internal positive motivation for senior students in the Military Medical Academy.

Questionnaire No. 2 included the following questions (rate on a 10-point scale):

1. How is the individual approach to each student in the English class implemented?

2. How do you assess the degree of communicative openness of the teacher in the English class?

3. How much can you assess the level of friendly attitude of the teacher towards you in the English class? 
4. How much can you assess the presence of negative factors in the interaction between the teacher and the cadets?

5. How much can you assess the degree of trust in the teacher?

6. How much do you assess the division of the group of cadets into "weak" and "strong"?

7. How interested are you in using authentic and relevant text materials and media resources in English?

8. How much does the teacher allow "success situations" to appear for lagging cadets?

9. How interested are you in working in small groups and educational design in English classes?

10. How useful do you find for yourself a flexible schedule and the availability of teacher advice?

The questions of the questionnaire, in our opinion, allow us to monitor not only the attitude to the subject, but also to evaluate the emotional state of students in English classes, since the high loyalty atmosphere is aimed at creating a warm emotional climate and the absence of stress during classes. The statistical data obtained as a result of an empirical study were processed in the "Neural Designer" program, which minimizes analysis errors and is a software tool for advanced analytics (descriptive, diagnostic, predictive analytics). The results of the study were evaluated on a 10-point scale, according to the learning motivation levels ("low" from 1 to 2 points, "average" from 3 to 4 points, "high" from 5 to 10 points).

\section{Research results}

The experiment results of the first stage showed that the motivation to learn English among senior students before applying the methodology to create an atmosphere of high loyalty was external (suggestive) in nature (Figure 1) and was at the lowest possible level. The data shown in Figure 1 allow us to conclude that the general level of motivation for studying English among senior cadets of the Military Medical Academy was low at the time of applying the methodology for creating an atmosphere of high loyalty. 


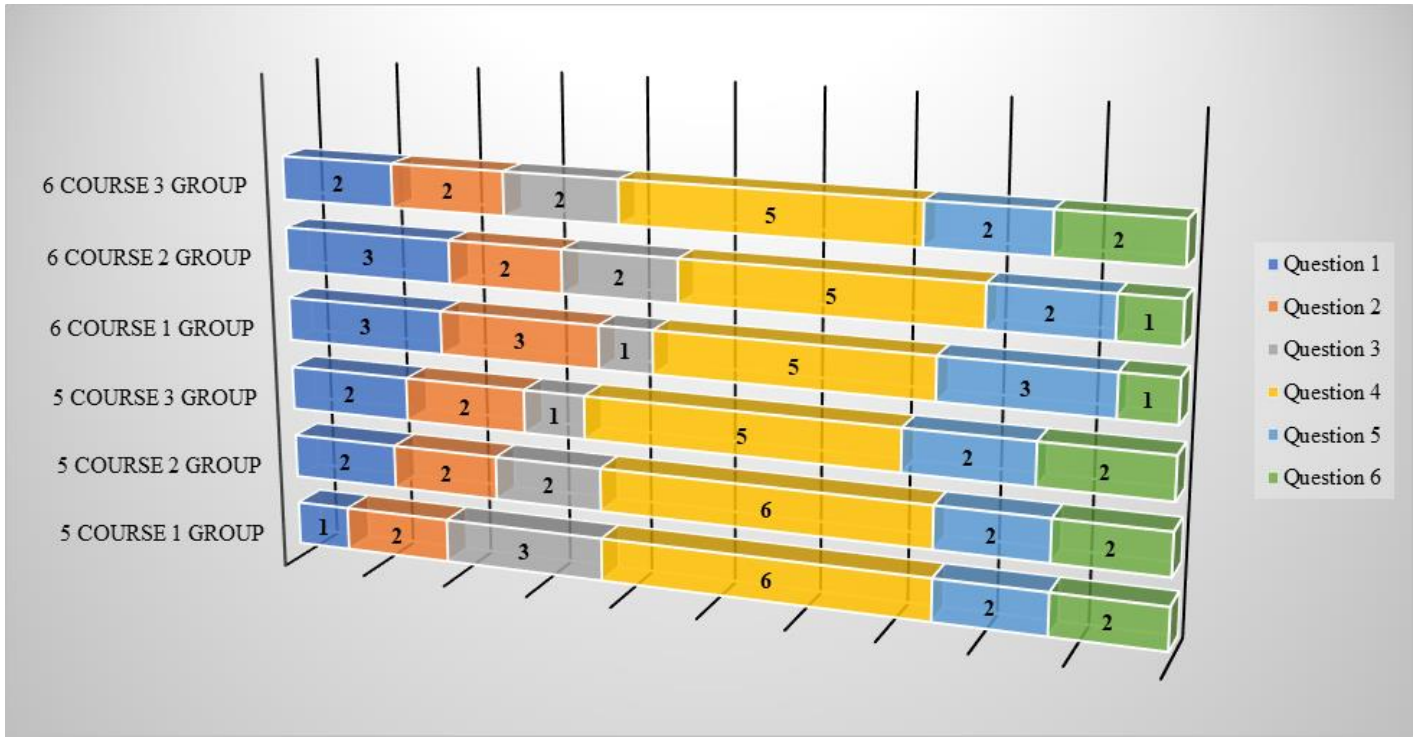

Figure 1. Assessment by students of the need to learn English and the conditions of its teaching before applying the methodology to create an atmosphere of high loyalty in English classes (on a 10-point scale)

At the same time, $50 \%$ of 5 th year and $60 \%$ of 6 th year students to the first question of questionnaire No. 1 "How important is it for the future military to learn English?" answered negatively, assessing the importance of learning English at 2 points. This indicator, in our opinion, is a key one, since the majority of cadets, before applying the methods of creating a high loyalty atmosphere in English classes, considered studying English language pointless for their future professional activities. To all subsequent questions of the questionnaire No. 1, equally negative answers were received. Based on the obtained data, we have identified a general level of motivation for learning English among students of the 5th and 6th courses of the military medical academy (Figure 2).

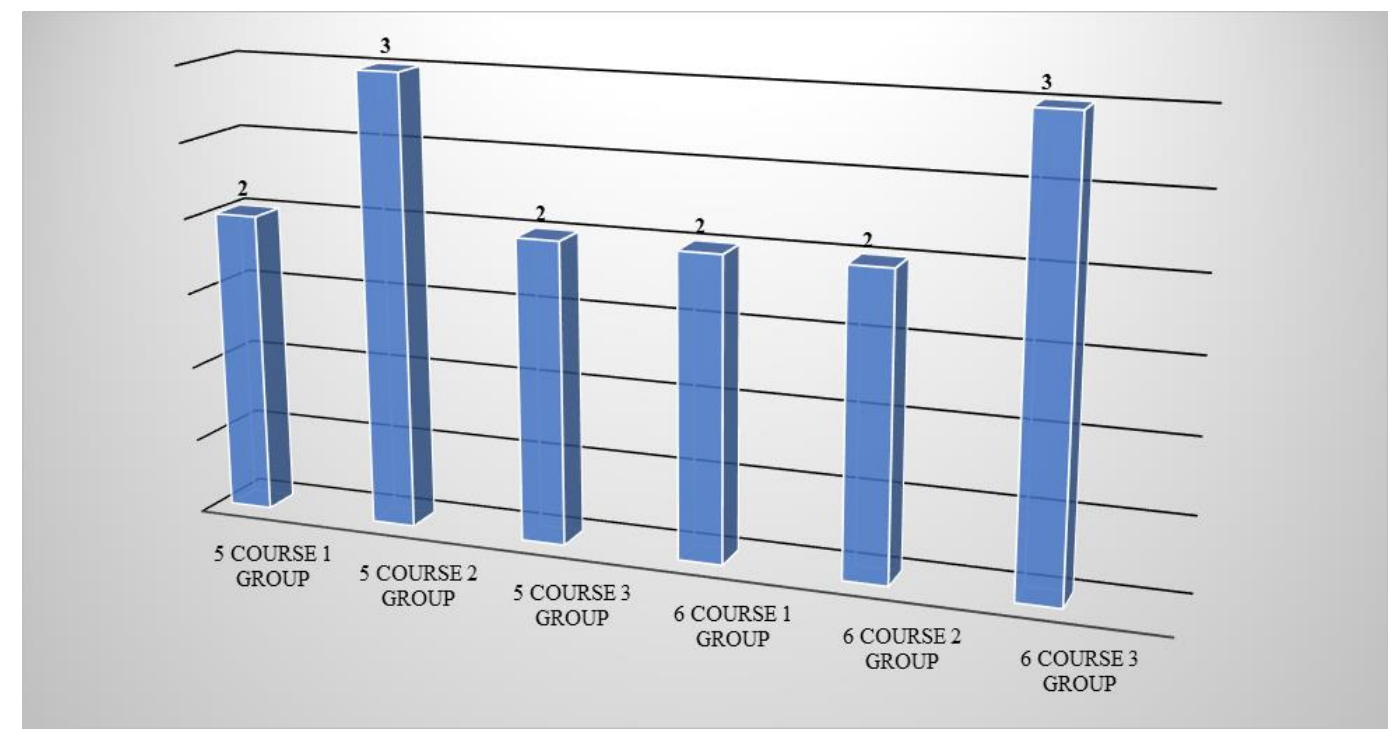

Figure 2. The level of motivation to learn English among students of the 5th and 6th courses of the Military Medical Academy before applying the technique of creating an atmosphere of high loyalty

In order to correct this situation, we applied a technique to create an atmosphere of high loyalty in the English language classes. First of all, the approach to teaching was changed: we 
replaced the classical version of teaching with a communicative approach with priority on the personal result of each student. Then we introduced all 10 conditions that we consider necessary to create an atmosphere of high loyalty. After conducting classes on the basis of this methodology, we conducted the second stage of an empirical study to assess the effectiveness of the proposed methodology.

The results of the questionnaire among senior cadets of the Military Medical Academy were processed in the Neural Designer program in order to calculate the average score for the answers presented in questionnaire No. 2. The final score of the students' assessment of the elements of the atmosphere of high loyalty is presented below (Figure 3).

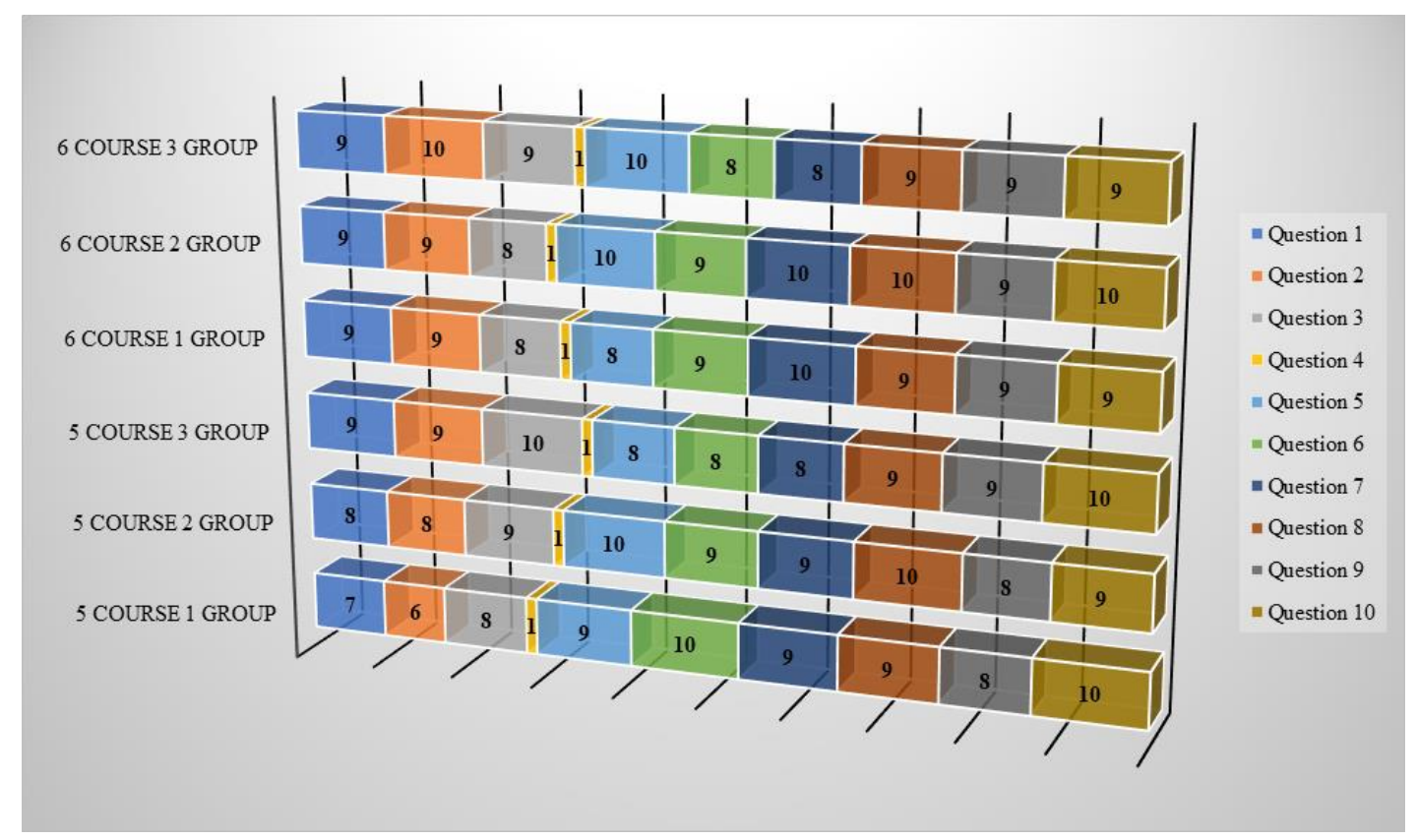

Figure 3. Average mark of students evaluating elements of the atmosphere of high loyalty

The data obtained as a result of the survey on the basis of questionnaire No. 2 allow us to say that the conditions (elements) of an high loyalty atmosphere, such as the opportunity to get a teacher's advice, received the highest assessment by students (question No. 10); openness and friendliness of the teacher (questions No. 2 and 4); as well as the level of trust in the teacher (question No. 5). Especially revealing is the answer to question No. 4 - the level of conflict in the classroom is practically absent. And this means that we were able to create a learning atmosphere without stress.

Such results allow us to conclude that it is the personal friendly attitude towards the cadets and the open communicative position of the teacher that are the central elements of the atmosphere of high loyalty in the English language classes at the Military Medical Academy.

Based on the obtained data, we conducted a repeated questionnaire on the form No. 1, which allowed us to identify the level of motivation for learning after classes based on the methodology for creating an atmosphere of high loyalty. The results obtained during the repeated 
questionnaire are presented below (Figure 4).

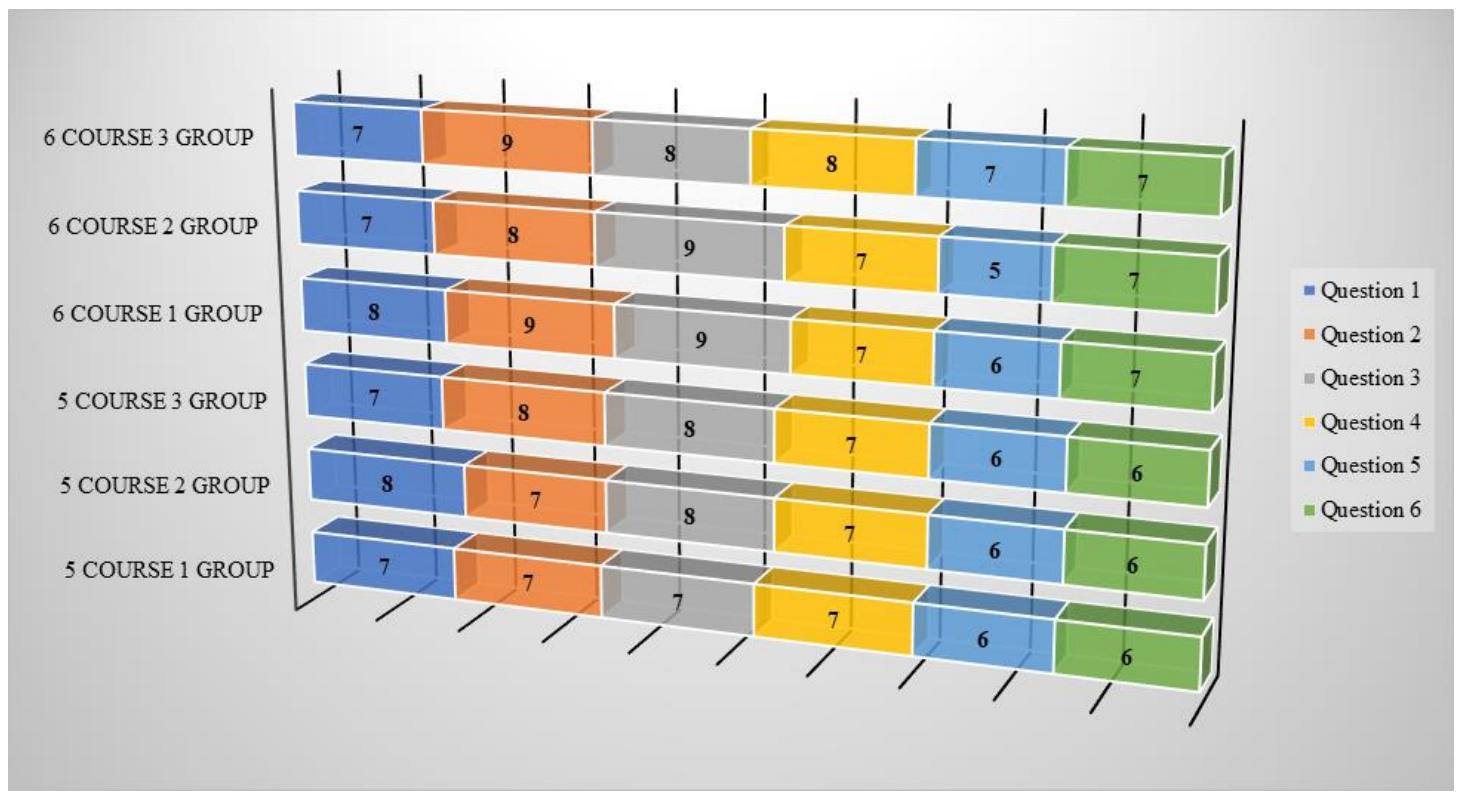

Figure 4. Assessment by cadets of the need to learn English and the conditions of its teaching after applying the methodology to create a high loyalty atmosphere in English classes (on a 10-point scale)

The data obtained as a result of a repeated questionnaire on the form No. 1 suggests that students of the 5th and 6th year of the Military Medical Academy, after conducting classes on the basis of creating a high loyalty atmosphere, positively and highly appreciated the need to learn English for their future professional activities, as well as for their personal development.

At the same time, it is interesting that practically the highest scores were given to questions No. 2 and 3, which indicates the formation of an internal, rather than external, positive motivation for learning. The final scoring obtained as a result of the repeated questionnaire revealed the following dynamics of the formation of positive intrinsic motivation before and after the lessons according to the methodology of creating the high loyalty atmosphere in English classes (Figure 5).

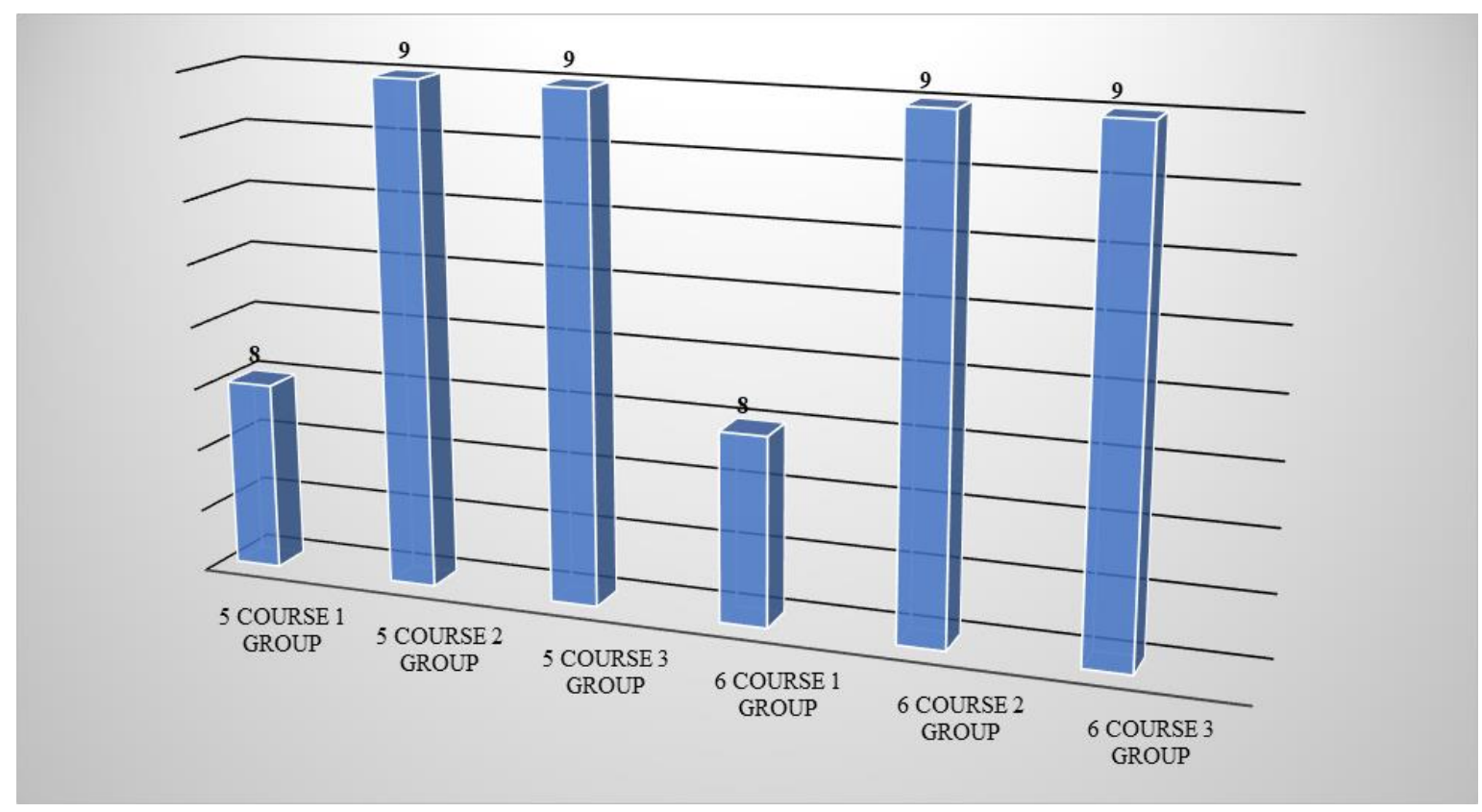


Figure 5. The level of motivation to learn English among students of the 5th and 6th courses of the Military Medical Academy after applying the technique of creating a high loyalty atmosphere

To increase positive motivation during the experiment, we used the problematic and partially search method, which form the basis of research activity. The use of these methods allowed to increase the cognitive activity of cadets, contributed to the awakening of their interest and conscious attitude to the subject; the formation of sustainable positive motivation for learning.

According to the results of the re-examination, we can note the active participation of cadets in practical work - active participation in project activities, in work in small groups. In general, our empirical study confirmed our hypothesis about a direct relationship between an atmosphere of high loyalty and the level of internal positive motivation for learning English among senior cadets of the Military Medical Academy. Undoubtedly, the result of our study cannot be interpreted as a long-term increase in learning motivation, however, the study conducted may be useful for the practice of teaching English in non-language university.

\section{Discussion}

The degree of scientific development of the learning motivation problems is quite high. The historiography on the studied issues can be divided into two main research directions. The first one consists of works by domestic and foreign researchers on the general problem of educational motivation of students. Researchers I. V. Chernovaljuk made a great contribution to the formation of a meaningful approach to the study of motivation problems as well as the research by N. Ellis (Chernovaljuk, 2019; Ellis, 2019). In particular, in the work by Yu et al (2019) the methods of teaching a foreign language, which can increase the motivation for learning are analyzed (Baryshnikova et al., 2019). The main points of these researchers are shared by O. Koval: he considers teaching methods as a factor in increasing the motivation of students in non-linguistic universities (Koval, 2019). Some new ideas about the possibilities of increasing internal motivation for learning can be found in Maksimenkova (2019). The theses of this author are shared in his article by Nazirova (2018). However, the idea of motivation formation using the appropriate learning environment is put forward only by Nosova (2020).

The second research direction is related to the study of the problem of new teaching methods and their impact on motivation. The problem of motivation formation in the framework of educational activities from the communicative approach perspective is considered in the works of such authors as: Preobrazhensky \& Choporov (2019). The influence of learning motivation has been studied in sufficient detail in the works of foreign researchers, in particular, the work by Sagimbayeva \& Moldakhmetova (2019) is interesting from the point of view of a systematic learning approach.

In most empirical studies, such as the article by E.P. Antonenko, motivation is defined as "a set of psychological reasons that explain a person's behavior, its beginning, orientation and 
activity" (Antonenko, 2016). In the context of our study, motivation can be considered as continuous choice and decision making based on an analysis of behavioral alternatives. According to Chiknaverova (2018), motivation determines the direction of actions, organization and stability of activities, the desire to achieve a specific goal.

Moreover, in the majority of both domestic and foreign studies, the structure of educational motivation is considered as a combination of personal meaning, a set of motives, goal setting, the implementation of a motive in behavior, as well as the emotional component. However, no correlation has been established yet between pedagogy and psychological conditions of learning and the formation of internal positive motivation.

For example, the work by Kolobaev and Sinitsyna (2020) addresses the issue of motivation for teaching students of non-philological universities. In the concepts of motivation, there are several classifications of motives for educational activity (Conference Proceedings, 2017: Moghadam, et al, 2019).

The first version of the classification proposes two large groups of motives. The first group includes cognitive motives related to the content of educational activities and the process of its implementation. According to Maksimenkova (2019), the motives of this group indicate the desire of students to master new knowledge, determine the depth of his interest in the subject. To this group Nazirova (2018) also refers to the motives for the formation of ways to achieve knowledge: methods of self-acquisition of knowledge, methods of scientific knowledge, methods of self-regulation of educational activity, rational organization of independent educational activity. According to Şahenk Erkan (2018), cognitive motives are a reflection of students' desire for self-education, for self-improvement of ways to replenish knowledge.

Another group is formed by social motives associated with various types of student interaction in society, from the communicative approach. At the same time, the motives of awareness of social necessity, duty and responsibility, quality preparation for choosing a future profession play a large role (Gabryś-Barker, 2016, p. 102).

Against this background, students of military universities may experience rejection and a negative attitude toward learning English, since it is not a key element of the curriculum and can only indirectly be correlated with the future professional career of the military. This aspect is practically not studied in the scientific literature. However, in some works one can find theses that non-core universities have all the opportunities for high-quality teaching of foreign languages and, in particular, English as the language of international communication (Suslova \& Kosterina, 2019, p. 224; Yaroshenko, 2019, p. 35; Zagoskina, 2019, p. 24).

In another version of the classification, the criterion is the ratio of motives in the educational activity itself. In the framework of this classification, motives are identified that stimulate a certain activity (in the context of our research, such activity is understood as learning), but not directly related to it (Antonenko, 2018, p. 9). 
The internal motives for learning are as follows: interest in the process of activity, interest in the result, desire for self-development, in the improvement of any of one's qualities or abilities (Conference Proceedings, 2017, p. 12).

External motives can occur if the educational activity is carried out only as a duty, an obligation, is considered as a way to achieve a certain formal educational result (Baryshnikova et al., 2019, p. 175). According to this classification, getting good grades is also one of the external motives. As can be seen from the above examples of motives, the external type is less stable and does not allow to achieve effectiveness in teaching foreign (Chernovaljuk, 2019, p. 7). According to Guseva 2020, the desire to comply with external parameters imposed by society, in particular, the immediate environment, stereotypes and social attitudes does not give longterm motivation, since when changing external parameters, such motivation can change to negative.

In our opinion, in all the above theses of both domestic and foreign authors, the problem of creating a positive learning environment as a factor in the formation of internal motivation is practically not considered. Therefore, we believe that the continuation of research to identify the correlation between an atmosphere of high loyalty and positive internal motivation one of the promising areas for both domestic and foreign pedagogy of higher education.

\section{Conclusion}

Based on the research results, the following conclusions can be drawn:

1. The motivation for learning activities among senior students of the Military Medical Academy is a complex concept and includes several groups of motives, the formation of which must take into account the psychological characteristics of training at a military university. The main task of the teacher in this case is not to allow the formation of negative motivation, in which the motive for avoiding failure dominates, but to create a high loyalty atmosphere to each student in the English language groups.

2. This empirical study suggests that the methodology for the formation of positive internal motivation, applied as part of the educational process at the Military Medical Academy, can contribute to a more lasting and deep mastering of knowledge, that allows to develop individual abilities, independent creative students' thinking, and most importantly, it creates the conditions for learning without stress and fear of failure.

The experiment we conducted as part of teaching English to senior students of the Military Medical Academy, clearly demonstrates that this teaching methodology has a great advantage over traditional teaching methods, although in the process of application it becomes necessary to divide cadets into small groups and apply new approaches to training (including the use of a communicative approach to teaching English). The indicated positive aspects of our methodology suggest that in creating a high loyalty atmosphere there is a wide potential for 
creating conditions for the maximum development of abilities, individual interests, and for satisfying the cognitive needs of senior students of the Military Medical Academy during the educational process.

3. The high loyalty atmosphere helps to increase motivation for learning among senior cadets and should be used in the work of the teacher on a systematic basis, not once. Otherwise there is the risk of lowering motivation or transforming motives from focusing on success to the desire to avoid failure increases.

4. As shown by an experiment conducted during the study, a high loyalty atmosphere of allows to increase the motivation to learn without stress from a negative assessment of the studied discipline by students.

In general, it can be noted that the problem of the lack of sustainable and positive motivation among students of non-language universities is characteristic not only of one specific experience of military cadets studied by us, but for the whole system of modern higher education in Russia for a number of reasons. The negative or skeptical attitude of teachers towards the latest teaching technologies, requiring a creative approach and taking a certain amount of time, as it is believed, "to the detriment of the rest of the curriculum," must be overcome through retraining and advanced training of the teaching staff of universities.

In the absence of a systematic approach to the study and monitoring of the motivation to study among cadets of military universities in the educational process, many problems arise that most higher military educational institutions in Russia face. As our study showed, the motive for avoiding failure is the most destructive for cognitive interest, it is, in fact, external, has no relation to the internal understanding of the meaning of learning. Moreover, such motivation, unfortunately, is actively supported and supported by the external environment. Thus, we can say that the problem of reduced motivation and the lack of cognitive interest in the process of learning English among students of non-language universities is a problem of the entire modern higher education system in Russia and requires the phased introduction of new methods on an ongoing basis.

\section{References}

Antonenko, E. P. (2018). Methods and practice of the development of lexical and grammatical mechanisms of unprepared spoken language while teaching a foreign language to cadets of a non-linguistic military university. Problems of modern teacher education, 3, 8-11.

Antonenko, E. R. (2016). On the experience of developing and applying locally standardized tests in teaching a foreign language to cadets of a military university. Philological sciences. Questions of theory and practice, 6, 180-183.

Antonian, I., \& Popovych, N. (2019). Use of Interactive Methods of Teaching Foreign 
Languages at Higher Educational Institutions. National Academy of National Guard of Ukraine. Linguistics, 3, 4-10. DOI: 10.12958 / 2227-2631-2019-1-40-108-117

Baryshnikova, Y. V., Emets, T. V., \& Vtorushina, Y. L. (2019). The system of work to prevent the interference of the native language when teaching English to undergraduate students in the pedagogical direction. Prospects for science and education, 6, 173-181.

Chernovaljuk, I. V. (2019). Linguocultural approach in the practice of foreign language education. Linguistics, 3, 3-14.

Chiknaverova, K. G. (2018). Interpretation and correction of errors in the speech of students of a foreign language. Review of foreign studies. Kazan Pedagogical Journal, 3, 129-135.

Conference Proceedings. (2017). The Future of Education: 7th edition.

Ellis, N. C. (2019). Essentials of a Theory of Language Cognition. Modern language journal. URL: https://doi.org/10.1111/modl.12532

Gerasimova, T. N. \& Guseva, N. V. (2019). The use of professionally adaptive testing in the process of teaching a foreign language to cadets of military universities. The world of science, culture, education, 3(76), 224-228.

Guseva, N. V. (2020). The use of information technology in the process of diagnosis of teaching a foreign language to cadets of military universities. World of science, culture, education, 1(80), 189-191.

Kolobaev, V. K., \& Sinitsyna, T. A. (2020). Some problems of teaching foreign languages in a non-linguistic university. The Scientific Heritage, 43, 47-50.

Koval, O. (2019). Project method of teaching foreign language higher education institutions students. Pedagogy of the Formation of a Creative Person in Higher and Secondary Schools, 2, 89-92. DOI: 10.32840 / 1992-5786.2019.63-2.18

Maksimenkova, A. C. (2019). The problem of the formation of students' motivation during their studies at the university. Bulletin of science and education, 1(55), 90-92.

Nazirova, O. M. (2018). The Importance of Student Motivation in Teaching Foreign Languages. ISJ Theoretical \& Applied Science, 10(66), 7-14.

Nosova, M. B. (2020). The results of the development of a methodological system aimed at the formation of discursive competence in the classes of Russian as a foreign language at a military university. Concept, 1, 51-64.

Gabryś-Barker, D. (2016). Positive psychology perspectives on foreign language learning and teaching. New York, NY: Springer.

Preobrazhensky, A. P., \& Choporov, O. N. (2019). On the problems of motivating students to study at a university. Russian Journal of Education and Psychology, 10(5), 62-65.

Sagimbayeva, J., Moldakhmetova, G., Kurmanayeva, D., Tazhitova, G., Kassymbekova, N., Smagulova, B., Tusselbayeva, Zh., Tussupova, G., \& Ustelimova, N. (2019). Experience and Perspectives of Teaching Foreign Languages at the L. N. Gumilyov 
Eurasian National University.

Şahenk, E. (2018). Teaching Foreign Languages. Academic Researches in Educational Sciences, 2, 55-69.

Suslova, Yu. V., \& Kosterina, N. M. (2019). Intelligence cards for teaching a foreign language to cadets of a military aviation university. Problems of modern teacher education, 3 , 224-227.

Yaroshenko, O. (2019). On the necessity of implementing the differentiation approach to teaching foreign languages at higher educational institutions. Pedagogy of formation of creative personality in higher and secondary schools.

Zagoskina, I. B. (2019). Motivation in teaching foreign languages at a non-linguistic university. Concept, 11, 2-7.

Moiseenko, Z. N. (2017). State support of small forms of management in agriculture: status and directions of development. Modern economy success, 12-17.

Moghadam, M. H. V., Mohammadi, M., \& Bazaey, G. A. (2019). Investigating effect of transformational leadership on employees' and administrators' satisfaction of telecommunication general department of district 3. Journal of management and accounting studies, 7(02), 24-30.

Narkevich, L. V., \& Narkevich, E. A. (2018). Financial condition analysis in the crisis management system. Russian Economic Bulletin, 1(4), 10-24.

Osipova, M. B. (2018). Tendencies of development of educational practice of the modern educational organizations. Modern Humanities Success, (1), 10-13.

Popov, V. P. (2018). Methodological aspects of teaching economic disciplines in a multi-level system of education. Modern Humanities Success, (3), 10-16.

Parizi, S. M. R., Moradi, H. R., Ravanbakhsh, A., \& Keshavarz, M. (2019). Anthropological study of the first decade of Muharram mourning ceremonies in Kerman. Journal of Social Sciences and Humanities Research, 7(02), 26-30.

Schwarzkopf, N. V. (2018). Improving the use of data mining technology as a way of reducing credit risk. Russian Economic Bulletin, 1(1), 10-18.

Sergeeva, M. G., \& Trubakova, D. I. (2017). Teacher's Reflection Formation as Factor of Effectiveness Children's Social Intelligence Forming. Modern Scientist, 7, 62-64.

Tsahaeva, A. A., Aminov, U. K., \& Aminova, D. K. (2017). Driving forces of the development of adaptive behavior of personality: methodological considerations. Modern Scientist, 8, 44-47. 